\title{
The Effect of Implementing Six Hats Teaching Method on the Performance of the 8th Grade Students in Islamic Education
}

\author{
Intisar Ghazi Mustafeh \\ Yarmouk University, Jordan
}

\begin{abstract}
This study aimed to investigate the effect of using Six-Hats teaching method on the students' achievement in Islamic Education curriculum at Yarmouk University model school. The researcher used the quasi-experimental design. The sample of the study consisted of (60) female students from Yarmouk University model school who were divided into two groups (experimental, control). The researcher prepared an achievement test that consisted of 30 multiple-choice items. The validity of the achievement test was confirmed with the help of a group of referees. The achievement test reliability was also confirmed by administering it to an experimental sample outside the study sample using (Cronbach Alpha), the calculated value was (0.91) which was considered appropriate for the purpose of the study. The results showed that there were statistically significant differences at $(\alpha=0.05)$ in the immediate and delayed achievement due to the teaching method ( Six-Hats method, conventional method) in favor of the Six-Hats teaching method. In the light of the results of the study, the researcher recommended that teachers should be trained to use Six-Hats teaching method in Islamic education classes.
\end{abstract}

\section{Introduction}

Change and development are significant characteristics in the different aspect of human life, a situation that pushes us toward more development and training related of the different creativity thinking skills that students must acquire, especially if we realize that thinking skills are a necessity for any developing society. Islam has called for thinking and creativeness, being as an honored creaturehumans - who were chosen by Allah and differed from all the other creatures Allah the almighty created, being specialized by thought and brain which gave them the ability to think and realize based upon the holly narrations of the Holy Quran and Sunnah (the prophet Mohammad sayings) which dealt with all humans' needs or knowledge.

The Holy Quran spoke about the importance of human brain and thinking skills and this was reflected by many Holy verses of the Holy Quran; like (behold! The creation of the heavens and the earth and the alternation of night and day, there are indeed signs for men of understanding) (Al Imran190), so the Holy Quran has considered the ability to think in the creation of Allah as one of the astonishing signs of the human of understanding, and the urge for knowing of the secrets of the universe as in (and pursue not of that which you have no knowledge for surely the hearing the sight ,the heart...) (Al Isra'-36) so all these verses call for using brain-the gift of Allah - in thinking, knowledge and rationalization. The Holy Quran revealed from Allah for guiding human race, and has provided all the suitable circumstances for launching thought, search and knowing all the facts in this world [1].

The Sunnah also related the different teaching methods of learning and developing thinking skills, so the Prophet Muhammad (pbuh) has taught his companions to discussed, argued and explain different issues, Sunnah is also distinguished with wisdom, rational regulation [2]. So the methods of teaching as one of the pillars of the teachinglearning process, and as much as the method suits the educational circumstances as much as students will gain the knowledge and the subject objectives will be achieved.

Educational experts and educators recommend that thinking skills must be developed nourished, and caring about it to enhance the students' motivation and performance or achievement which will result at the end in permanent learners and better motivated students. Thinking has an important effect in developing students rationalization, and improve their problem solving skills, coping with life and high tech revolution [3][4]. In addition to that thinking helps societies and individuals in coping with life and understanding the universe or the world we live in. Six-Hats teaching method helps students to focus thinking and communication, provides selfmonitoring strategies that lead them to better teamwork [5].

Generally, developing the creative thinking skills is one of the major goals of modern education and the Six-Hats teaching method is one of the DeBono's thinking model that aims for enhancing thinking and simplifying it at the same time. Six-Hats teaching method, which will be the major focus of this research-is regarded as one of the best creative thinking model, DeBono believes that this model is a great teaching method for thinking skills, because the students can - by this model-deal with one thing only at the same time, while changing their thinking style [6].

Gittomer regards the Six-Hats method as a classic model of creativeness where time is used for achieving a certain goal [7]. While Jervis defines it as: a method used for simplifying the problem, 
because this model makes a room for using different thinking styles [8]. Curran has indicated that the objectives and the characteristics of this model are: exemplifying and simplifying thinking and better efficiency where the student change or turn from shallow into deep thinking and achieving flexibility in thinking styles, developing thinking skills, and equipping students with different subjects at the same times. While the characteristics of this program are embodied by the following: easy learning and teaching, practice and using it in different levels of education, nurturing attention, enhancing decision making, bettering communication, and acknowledging the important role of emotions in thinking expressing love or hate by students [9].

Gross added another traits or characteristics for the Six-Hats model regarding using the brain capacities and achieving varicosity, General and partial thinking, enabling students to better listening and increasing their learning efficiency [10]. While Borowsky said that this method or model can share the language, so any person can read your problems to you can wear the black hat, which will help you in feedback [11]. Carl has mentioned a number of characters for the model like the variety of thinking styles, helping the student in using different thinking style at every case, motivating the student for preparing a thinking plan, limiting arrogance and developing self sufficiency [12].

DeBono indicated the importance of the teaching method in teaching thinking which is flexible for the students learning, so that when the students changes their hat, they will see the things from a different perspectives or opinions, which leads to more openness for the students. So when the students wear the same colored hat they will be away from any argument or separation, and you feel the same way like your peers, sympathies with them or understand how they feel or think [13]. DeBono has divided human thinking to six styles and that every hat wore by the students or take of represents the thinking style the student use, and to simplify their model which has given a special color for every hat were it can be easily seen and memorized. There are different ways of thinking as DeBono indicated:

- The white color hat represents thinking neutrally.

- The yellow color hat represents thinking positively.

- The green color hat represents thinking creatively.

- The black color hat represents thinking pessimistically.

- The red color hat represents thinking emotionally.

- The blue color hat represents thinking thoughtfully [6].

Each hat has its significations: the white hat represents thinking by depending on facts and precious information and it represents thinking neutrally and characterized by subjectivity. The red hat represents thinking emotionally, where the feeling and emotions is the backside of the reality. The black hat thinking represents thinking negatively. It is the critical thinking that is based upon logical reasons and motives and thinking about faults and past pitfalls a thing that is necessary when the individual wants to make a decision. The green hat represents creative thinking where it presents solutions and different alternatives and new ideas that cope with abilities and capacities and it aims towards nurturing creativeness. While the yellow hat thinking represents thinking positively and ambitiously which is the other way around of the black because it increases or supports the positive sides of thinking but it must be based on logical justifications which indicates reflective thinking and value adding. Finally the blue hat thinking represents the guide for the other thinking styles and determines which is useful and the time suitable for changing or moving to other thinking style and a holistic thinking style when dealing with any issue .It is not true hat but psychological positions or situations that are empathized during discussion groups or meetings or during individual thinking [14], [15], [6].

\section{Using the Six-Hats teaching method}

Any individual can think in six ways or styles while using the Six-Hats, so when he changes the hat he changes his thinking style, he can use it individually, respectively, organized or spontaneously [16].

There isn't any special order followed when using Six-Hats teaching method of this model while changing the Six-Hats, and the students can apply this flexibly, but its preferred to begin with the white hat to collect information and end with the blue for focusing on the students and their learning, Ibrahim believes that the white hat should used at the begging because it used to collect information, and the blue hat at the end in briefing what to be used of thinking styles, and there is no sequence in using the other four hats here but its preferred to use the green after the yellow because the creative thinking need positivity. It is not necessary to use them all in one lesson, you can use some of them in the lesson [17].

So the Six-Hats teaching method of DeBon's thinking model allows the students to inquire information with the white hat, to express their feelings with the red, to think critically with the black, to create and present new solutions with the green, to guide and supervise the process with the blue which suits parallel thinking and ending or discarding the converted thinking [18].

Teaching method of this model is the first step practically determined in the curriculum, and the importance of Six-Hats teaching method is 
represented by the supporting the students skills, and prepare them creatively. the students must cope and face their age problems due to the continuous development the human race witnesses, and that is reflected by the teaching methods adopted at this side and to care about it as one of the learning process as thinking is regarded one of its components and there must be teaching methods followed in learning, providing the suitable context, and to cope the students to move away from the listener role to take part in their learning process [19] and the ability to determine those objectives that can be achieved by the Islamic education curriculum directly [20].

\section{The previous studies}

Keeny conducted research aimed at using the Six-Hats teaching method to enhance creativity thinking for health care students. The sample consisted of nursing school, it used the experimental designed. The students wore the different hats color and discuss different issues related to the subjects. The study revealed that the Six-Hats teaching method enhanced the different thinking skills [21]. Alazawi conducted research aimed at exploring the effect of using Six-Hats thinking strategy on the preparatory students in Islamic education curriculum. The study population consisted of the Deyali schools $2010 / 2011$, while the study sample consisted of the $4^{\text {th }}$ elementary students 49 students divided into groups, one was taught using the conventional method the other was taught by using the Six-Hats thinking strategy. The research result shows that there is a statistical differences in the favor of the experimental group that taught by using Six-Hats [20]. While Kaya tried to find the effect of six thinking hats on student success in teaching subjects related to sustainable development in geography classes. This study aimed to assess the effectiveness of six thinking hats technique in teaching subjects related to sustainable development in geography classes. The study was in both quantitative and qualitative form, the quantitative part of the study was design to pre-test, post pre test control group research model. In the qualitative part answers given by students interview questions were analyzed according to descriptive analysis method. The population of the study consisted of 650 students studying in Araban High school and the sample consisted of 36 of 11 th grade students. The results revealed that teaching techniques based on six thinking hats more positive results compared to other teaching techniques proposed in the curriculum [22].

\section{Statement of problem and research questions}

Depending on the previous statements the researcher believes that the Six-Hats thinking model is regarded important and worth searching upon its relation to improve thinking skills specifically and to the educational process generally, students' motivation, and modern education. So this research aims at exploring the effect of using the Six-Hats teaching method (DeBono's thinking model) on the achievement of the $8^{\text {th }}$ grade students in Islamic education so, this research tried to answer the following questions:

- Are there a statistically significant differences at $\alpha=0.05$ between the means of the students' achievement in Islamic education due to teaching method (Six-Hats teaching method and the conventional method) in the achievement immediate test?

- Are there statistically significant differences at $\alpha=0.05$ between the means of the students' achievement in Islamic education due to teaching method (Six-Hats teaching method and the conventional method) in the achievement follow up test?

\section{The research significance and importance}

This study aimed to explore The effectiveness of using the Six-Hats teaching method (De Bono's model) on the achievement of the 8th grade students in Islamic education (the Islamic morality system unit), and upon the dearth of studies at about using this method in Islamic education curriculum we realize the importance of the research that the gap could be filled upon its relation to information economy, thinking styles. So that students can move from the subtle memorization of information thinking to the stage of developing their skills of analysis and, knowledge, launching other researches at this area.

\section{The procedural definitions}

\subsection{The Six-Hats teaching method}

It is a method used to teach the $8^{\text {th }}$ grade Islamic education students that is based on developing creativeness, enhancing thinking, and the freedom of using any thinking style by the students so that the thinking style the students use will be according to the hat color upon the following steps applied by the teacher: determining the problem, determining the group goals, applying the hats method upon using 
different hats and thinking styles related to it, and according to the learning position of the students.

\subsection{Achievement}

The level that the students had attained out from the learning process, and it is measured by the Islamic education achievement test prepared and applied by the researcher before and after the study application.

\subsection{The conventional method}

A group of steps and procedures, which followed by the teacher when they explaining the lesson for the students including the introduction, the contents and the evaluation of the lesson.

\subsection{The effect}

The effect is the differences in the students' achievement, due to the teaching method (Six-Hats teaching method). The students degrees that achieved by the students participating in this experiment in the post achievement test prepared by the researcher for the Islamic education.

\section{Research limitations}

The results of the study can be generalized upon the following circumstances:

- The research sample is consists of two groups of 8th grade students at the Yarmouk University Model School during the school year of 2013/2014.

- The research tool: is the achievement test prepared by the researcher to achieve the research aims. The degree of results generalization can be applicable upon the accepted psychometric characteristics of the achievement test.

- The study included one unit of the Islamic education curriculum for the $8^{\text {th }}$ grade which is titled' the Islamic morality system.

\section{The variables of this research}

The independent variable: is the processing method used (quasi-experimental design), with two levels a group that was taught using the Six-Hats teaching method while the other is taught by using the conventional teaching method (experimental and control groups). The dependent variable is the female students' achievement.

\section{Method and procedures}

The researcher dealt with describing the study population, the method used in selecting the sample, the steps of preparing the achievement test, the methods used in verifying the tool used and its reliability, besides shedding the light on the study procedures, design and statistical analysis.

\subsection{The research design}

This study is regarded as one of the experimental researches made at this side where the researcher used a pre and post-test method for both groups, so the Six-Hats teaching method was used with the experimental group, while the control group was taught by the conventional teaching method used at schools.

The pre-test, post-test, and the control group design. Alassaf stated that at this design individuals or participants are chosen and distributed for two groups randomly that is followed by a pre-test, then the experimental group is tested by the independent variable, not the control group, after the experiment ended a post-test is made for both groups to measure the impact of the independent variable application, then the achievement test is made for both groups [23]. In this study, the experimental group is taught by the Six-Hats teaching method, while the control group is taught by the conventional methods, then after the experiment finish, the effect of the Six-Hats teaching method is measured by using immediate and follow up test, and then the results are analyzed to measure the effect of the independent variable.

\subsection{The research population and sample}

The study population was all the 8 th grade students in Irbid first directorate (3961 male, 4073 female) students, while the sample was made up of the sample consists of the female students chosen randomly from the population. There were two female classes (30 students each) chosen from Yarmouk University model school due to the easiness and applicability. Due to the study objectives the researcher had used the following tool:

\subsection{The achievement test}

After the researcher reviewed the previous studies and literature review related to the statement of problem, where the researcher had prepared the achievement test in Islamic education according to the following steps: determining those lessons contents for it, phrasing the test items, preparing an experimental test, then verifying the test by a group 
of teachers specialized and had experience in this field.

After the researcher reviewed the previous literature related to the statement of problem and the previous studies tools related, where the researcher had prepared the achievement test to suit the study objectives in order to measure the students achievement in the Islamic morality system unit of the 8th grade Islamic education curriculum (the first semester 2013/2014), the test was made up of multiple choice items because this type of the test covers most of the text [24], and the questions were built according to bloom taxonomy as follows: memorizing, understanding ,synthesis, analysis, practice, evaluation.

The test was prepared according to the following steps:

- The lessons were chosen from the Islamic morality system unit for the 8th grade Islamic education curriculum.

- The taught unit was analyzed, the concepts were explored, and the generalizations in it according to the bloom taxonomy. The questions levels were categorized in special table a according to bloom taxonomy.

- The test items prepared by the researcher constituted from 30 multiple choice items, with four choices for every question or item and that immediate test was prepared in order that the researcher can assess the students performance after the unit is being taught and the follow up test after two weeks, the achievement test has instructions cleared for the students at the beginning of the test to make sure how they can deal with the test and answer the test questions or items.

\subsection{The achievement test validity}

To verify the test validity the tool was reviewed and verified by a group of experts specialized in Islamic education and in evaluation and measurement from Yarmouk University, and commenting on it by adding or omitting some of the items and its congruence with the teaching goals, the concepts relatedness, and the generalizations made about the unit taught for the female students, the contents language, any editing or remarks seen suitable at this side. Upon the experts remarks and making the recommended editions $80 \%$ of them mentioned as follows: omitting some items because it was contradicted with other items, phrasing, and the need for adjustments, with 30 items at last.

\subsection{The achievement test reliability}

A pilot study out of the research sample was made in order to assess the study reliability, the researcher computed the cronbach alpha variable with internal consistency (0.91) which is a high percentage and signifies a high level of internal consistency for the test (as a test for reliability)which suits the current research.

\section{The procedures}

\subsection{The control procedures}

In order to have suitable and safe results general and applicable, the researcher made a practical pretest for the achievement of both groups; means and standard deviations were computed. The results showed that there are not a statically significant differences at $\alpha=0.05$ between both groups means for the pre-test, which reflects the sample homogeneity and sufficiency.

\subsection{The experimental procedures}

After choosing the sample randomly and the assurance of the two groups sufficiency, the researcher had adopted the achievement test for the pilot study in order to assure the validity and reliability of the test ,the achievement test was reprepared and the means and standard deviations were computed to assess the results neatness, then the researcher prepared a group of lessons for the "Islamic morality system" unit of the Islamic education curriculum for the $8^{\text {th }}$ grade according to the Six-Hats method.

The researcher then trained the Islamic education teacher to use to teach the experimental group according to the study design so that the experimental group will be taught the moral unit according to the Six-Hats method while the control group was taught according to the conventional methods. After completing the experiment the researcher has made the immediate and delayed tests for the students. The immediate achievement test was applied directly then the follow up achievement test was held after two weeks of the study, then the tests were corrected by the researcher and collecting the information besides analyzing it statistically by using the (ANCOVA) and putting down discussions and recommendations.

\section{The statistical analysis}

To answer the research questions, the researcher used the (SPSS) package means and standard deviations were computed and the (ANCOVA) to compare between the means. 


\section{The results}

The research first question: are there a statistically significant differences at $\alpha=0.05$ between the means of the students' achievement in the Islamic education due to the teaching method (SixHat method and the conventional method) in the achievement immediate test?

To answer the research first question, means and standard deviations for the respondents were computed and Table 1 shows means and standard deviations for the respondents (experimental and control group) due to the teaching method.

Table 1.The means and standard deviations of the students' achievements in the pre and immediate tests due to teaching method

\begin{tabular}{|l|c|c|c|c|c|}
\hline \multirow{2}{*}{ Teaching method } & & \multicolumn{2}{|c|}{$\begin{array}{c}\text { Pretest } \\
\text { (Covariate) }\end{array}$} & \multicolumn{2}{c|}{ Immediate } \\
\cline { 3 - 6 } & & Mean & $\begin{array}{c}\text { Std. } \\
\text { Dev. }\end{array}$ & Mean & $\begin{array}{c}\text { Std. } \\
\text { Dev. }\end{array}$ \\
\hline Conventional & 20 & 8.70 & 1.22 & 11.80 & 1.28 \\
\hline Six Hats & 27 & 8.44 & 1.19 & 15.56 & 1.15 \\
\hline
\end{tabular}

As we can see from Table 1 we can realize that there are differences at $\alpha=0.05$ in the achievements of the students in Islamic education for both group due to the teaching method. The differences have been shown to be statistically significant at $\alpha=0.05$ by using (ANCOVA) procedure see Table 2. The results show that there is a significant difference on the students' achievements due to the teaching method in the favor of the Six Hats teaching method as in Table 3. The effect size of using the Six-Hats teaching method is $70.79 \%$, which conceder to be a big effect in teaching Islamic education to the $8^{\text {th }}$ grade students due to using Six Hats teaching method.

Table 2. The ANCOVA procedure on the students' immediate achievements test After excluding the effect of the students' achievement in the pre test

\begin{tabular}{|l|c|c|c|c|c|c|}
\hline \multicolumn{1}{|c|}{ Source } & $\begin{array}{c}\text { Sum of } \\
\text { Squares }\end{array}$ & df & $\begin{array}{c}\text { Mean } \\
\text { Square }\end{array}$ & $\mathbf{F}$ & Sig. & $\begin{array}{c}\text { Partial } \\
\eta^{2}\end{array}$ \\
\hline Pretest (Covariate) & 0.73 & 1 & 0.73 & 0.49 & 0.49 & $1.10 \%$ \\
\hline Teaching method & 157.90 & 1 & 157.90 & $\mathbf{1 0 6 . 6 5}$ & 0.00 & $70.79 \%$ \\
\hline Error & 65.14 & 44 & 1.48 & & & \\
\hline Total & 227.91 & 46 & & & & \\
\hline
\end{tabular}

Table 3. The students' achievements immediate test means and standers deviations

\begin{tabular}{|l|c|c|}
\hline Teaching method & Mean & Std. Error \\
\hline Conventional & 11.82 & 0.27 \\
\hline Six Hats & 15.54 & 0.23 \\
\hline
\end{tabular}

The second question: Are there statistically significant differences at $\alpha=0.05$ between the means of the students' achievement in the Islamic education due to teaching method (Six-Hats teaching method and conventional method) in the achievement follow up test? To answer the research second question the means and standard deviations were computed for both groups (experimental and control group), and Table 4 shows the means and standard deviations were computed for both groups due to the teaching method.

As we can see from Table 4 we can realize that there are differences at $\alpha=0.05$ in the achievements of the students in Islamic education for both group due to the teaching method. This difference has been shown to be statistically significant at $\alpha=0.05$ by using (ANCOVA) procedure (see Table 5). The results show that there is a significant difference in the students' achievements due to the teaching method in the favor of the Six Hats teaching method as in Table 6. The effect size of using the Six-Hats teaching method is $88.09 \%$, which conceder to be a big effect in teaching Islamic education to the $8^{\text {th }}$ grade students in keeping the information due to using Six Hats teaching method.

Table 4. The means and standard deviations of the students' achievements in the pre and follow up tests due to teaching method

\begin{tabular}{|l|c|c|c|c|c|}
\hline \multirow{2}{*}{ Teaching method } & \multirow{2}{*}{$\mathbf{N}$} & \multicolumn{2}{|c|}{$\begin{array}{c}\text { Pretest } \\
\text { (Covariate) }\end{array}$} & \multicolumn{2}{|c|}{ Follow-up } \\
\cline { 3 - 6 } & & Mean & $\begin{array}{c}\text { Std. } \\
\text { Dev. }\end{array}$ & Mean & $\begin{array}{c}\text { Std. } \\
\text { Dev. }\end{array}$ \\
\hline Conventional & 20 & 8.70 & 1.22 & 8.50 & 1.61 \\
\hline Six Hats & 27 & 8.44 & 1.19 & 15.44 & 1.01 \\
\hline
\end{tabular}

Table 5. The ANCOVA procedure on the students' follow-up achievements test after excluding the effect of the students' achievements in the pre test

\begin{tabular}{|l|c|c|c|c|c|c|}
\hline \multicolumn{1}{|c|}{ Source } & $\begin{array}{c}\text { Sum of } \\
\text { Squares }\end{array}$ & df & $\begin{array}{c}\text { Mean } \\
\text { Square }\end{array}$ & $\mathbf{F}$ & Sig. & $\begin{array}{c}\text { Partial } \\
\boldsymbol{\eta}^{2}\end{array}$ \\
\hline Pretest(Covariate) & 2.74 & 1 & 2.74 & 1.65 & 0.21 & $3.62 \%$ \\
\hline Teaching method & 539.49 & 1 & 539.49 & 325.50 & 0.00 & $88.09 \%$ \\
\hline Error & 72.93 & 44 & 1.66 & & & \\
\hline Total & 629.74 & 46 & & & & \\
\hline
\end{tabular}

Table 6. The students' achievements follow up test, means and standers deviations

\begin{tabular}{|l|c|c|}
\hline Teaching method & Mean & Std. Error \\
\hline Conventional & 8.53 & 0.29 \\
\hline Six Hats & 15.42 & 0.25 \\
\hline
\end{tabular}

As we can realize from Table 6 for the experimental group which reflects the permanent impact of such a program on the experimental group and that they still memorize the information.

\section{Results}

The discussion of the research first question: Are there a statically significant differences at $\alpha=0.05$ in the students, achievements in Islamic Education due 
to teaching method (Six-Hats teaching method, conventional method) in the immediate achievement test?

The results showed the out performance of the experimental group taught by the Six-Hat method was better compared to the control group taught by conventional method, and the researcher believes that this result could be attributed to the following: Six-Hat method is more efficient than the conventional methods of teaching in Islamic education, using the Six-Hat method helps students to develop the higher thinking skills, nurturing creativity. Changing the hats also affected the students positively which leads to develop their thinking skills generally. The 8th grade students are in a grade that suits to be taught by using Six-Hat method. The Six-Hats teaching method helps Islamic education teachers in comprehending the Islamic education subjects and bettering their achievement levels and this result is in agreement with the results of Alazawi [3].

The discussion of the research second question: Are there a statically significant differences at $(\alpha=0.05)$ in the students, achievements in Islamic Education due to teaching method (Six-Hats teaching method, conventional method) in the follow up achievement test? The result showed that the experimental group taught by the Six-Hat method kept the information longer compared to the control group taught by conventional method, and the results could be also attributed to the flexibility of this method regarding the individual emotions expression where the student moves from one style to another and expressing their ideas and thinking at the same time, practicing criticizing, expressing emotions, thinking positively and employing the thinking styles, which enable students to keep the information and memorize it for longer time than the students who taught by the conventional teaching method, this result is congruous with other studies such as [25 ], [26], [27] and [28].

\section{Conclusion and Recommendations}

From the results of this research, it can be seen that using the Six-Hats teaching method is better than using conventional teaching method in Islamic Education classes and it affects the students' achievements. The teachers should therefore try as much as possible to use the in collation of this method among students. Based on these results the following recommendations were made:

- Islamic Education teachers should be participate on workshops, seminars and training in the skills that allow them to use suitable teaching methods that improved thinking skills such as the Six-Hats teaching method.
- The curriculum designer for the 8th grade should restructure to be suitable to enhance thinking skills.

- Pedagogical training of teachers should incorporate the in-depth research of various teaching methods of Islamic education task presented to pupils especially the Six-Hats teaching method.

\section{References}

[1] Abdullah Khawaldeh, N., Smadi,M., (2001). Introduction to Islamic Education Curriculum and Teaching Methods. (2) DarAlforqan:Amman.

[2] Albashari, H., (2000). Teaching Aids that Used b Prophet Mohammad (pbuh).( 1), Ministry of Islamic Affairs, Qatar.

[3] Alhur, A., (2001). Future School. Dubai: Arab Educationl Office.

[4] Alowysi, R., (2001). Thinking (Skills, Teaching Strategy). Book Center:Cairo

[5] Rizvi, A., Bilal, M., Asdaque, M., (2011). Application of Six Thinking Hats in Education. Vol 3 No. 3. Educational Journal of Academic Research.

[6] De Bono, E., (2005). Serious creativity (Translated to Arabic by Alnory). Alriyadh.

[7] Gitomer, D., (2000). Imagination Beats Knowledge Hands Down, Long Island Business News, 47, (42)33-A.

[8] Jervis, C., (1998). Using Postman and De Bono as Guiding Principles in Interdisciplinary Standards Based Approach to Technology Anylasis for Secondary School Students, ERIC.ED429551.

[9] Curran, K., (2003). Thinking Hats in Classroom Meeting, Middle Years Educator, 1 (3), 1-11.

[10] Gross, R., (1998). Peak Performance: The SixHats, Armed Forces Comptrollers, 34 (3), 38

[11] Borowsky, G., (1994). What Color is your Hat? Executive Report, 13(1), 1-6.

[12] Carl, W., (1996). "Six Thinking Hats: Argumentativeness and Response to Thinking Model" NIA, (ED 399576)

[13] De Bono, E., (2001). Six Thinking Hats. Abu Dubi: Al mojam'a Al thaqafi. 
[14] Bikar, A., (1999). Introduction into Comprehensive Development from Islamic Point of View. (1). Dar Alqalam: Demascus.

[15] Suruor, N., (2005). Risk Prorgramme for Creative Thinking, DeBono Publisher: Amman.

[16] Nofel, M.(2009). Creativity: Concepts and Application.DeBono Publisher: Amman

[17] Ibrahim, A., (2010). The Effectiveness of Using Six-Hats in the Fifth Grade Students Achievement and Decision Makers. Swhaj University, (28), 311385.

[18] Gregory, S., Masters, Y., (2012). Real Thinking with Virtual Hats: A role playing activity for preservice teachers in second life. Australasian Journal of Educational Technology, 28 (special issue, 3) 420446.

[19] Shafe', I., Kotheri, R., Seralhkatem, O., (1996). School Curriculum : New Prespectives. Alryadh: Alabycan Library.

[20] ALazawi, K., (2012). The Effect of Using the Six-Hats in the Achievement of Preparatory Students in Islamic Education Curriculum. Alfath Journal, (48), 143-174.

[21] Keeny, L., (2003) “Using Edward De Bono's Six-Hats Game to Critical Thinking and Reflection inPalliative Care, Retrieved" July 26, International Journal of Palliative Nursing. 3003, Vol. 9, No. 3

[22] Kaya, M., (2013).The Effect of Six-Hats on Student Success in Teaching Subjects Related to Sustainable Development in Geography Classes Educational Sciences: Theory \& Practice-13(2) Spring 1134-1139.

[23 Alassaf, S., (2006). Introduction to Educational Research (4), Alryadh: Alabycan Library.

[24] Zaher, Z., Tamerjan, J., Jawdat, A., Fejal, A., (1999). Prenciples of Educational Statistics. Dar Althaqafeh: Amman.

[25] Odat, M., (2006). The Effect of Using Brainstorming, the Six-Hats and the Effective Lecture Methods on the Tenth Grades Achievement and Reflective Thinking in the Citizenship and Civil Education Textbook .Unpublished Thesis, Yarmouk University. Jordan

[26] Alhusieny, F., (2012). The Effectiveness of Teaching Arab World Geography for Tenth Grade Students at Al Kuwait by Using the Six-Hats and its
Effect on Their Achievement and Critical Thinking. Unpublished Thesis, Middle East University.

[27] Alotaibi, M., (2013). The Effectiveness of Teaching Strategy, Six Thinking Hats in the Educational Achievement and Interests Towards Biology by the First Secondary Grade Students in Holy Makka city.Om Al Qura University Journal, 1(5). 144-174

[28] Alshaya, F., Alogaiyl, M., (2009). The Effect of Using the Six Thinking Hats in Teaching Science on Developing the Creative Thinking and the Lexical Class Coopration for the Pupils in the Primary School in Riyadh. Derasat Journal, 1(2), 19-56. 